\title{
Classroom teachers' professional development activities within the scope of life long learning in Turkey ${ }^{1}$
}

\author{
Aliye Erdem ${ }^{2}$ \\ E. Seda Koç
}

\begin{abstract}
Among all the factors affecting education, teachers have more important role in ensuring the effectiveness of the teaching process. Teachers' professional development is a subject that directly affect the teaching process. Researches on the development of teaching profession indicate that professional training is a necessity for better education and better schools. Because if the teacher learns during performing the teaching profession, the quality of the education offered by the teacher will be higher. Teachers who develop themselves in terms of profession provide both a better education and a positive learning environment for the students. In this context, the aim of this research is to investigate the activities of the classroom teachers participate in Turkey in order to ensure their professional development. The study is prepared depending on the views of the classroom teachers. The data were obtained from the classroom teachers who teach 1,2,3, and 4. classes in public and private elementary schools in Ankara, in the 2014-2015 academic year. Questionnaire developed by the researchers was used for collecting the data.
\end{abstract}

Keywords: Classroom Teachers; Professional Development; Professional Development Activities.

\section{Introduction}

Teacher is basic element of education system because the success of education system depends on the qualifications of all education staff and teachers that are basic practitioners of this system. Teaching requires some skills and talents such as accumulation of knowledge, planning period, field information, advanced linguistic skill, familiarity to technological advancements and skill of using technological tools, recognizing and guiding students having different characters and levels, effective communication. Being in the guidance of teachers having these qualifications will bring reaching the desirable point in terms of education quality for the students receiving this education (Gürlen and Demirel 2010).

The change in society and family as well as technological and cultural changes affect not only curriculums but also dynamics of class and school at the same time (ETUCE 1995). Teachers play a key role in not only transferring of culture but in preparing of students. The success of student

\footnotetext{
${ }^{1}$ This article was submitted at 1 st International Conference on Lifelong Education and Leadership for All-ICLEL 2015 2 Assistant Professor, Ankara University, Faculty of Educational Sciences, Department of Elemantry Education, aliye.erdem@ankara.edu.tr

3 Assistant Professor, Kastamonu University, Faculty of Education, Department of Educational Science, eskoc@,kastamonu.edu.tr
} 
Erdem, A., \& Koç, E. S. (2016). Classroom teachers' professional development activities within the scope of life long learning in Turkey. International Journal of Human Sciences, 13(1), 1503-1513. doi:10.14687/ijhs.v13i1.3698

depends on qualified education whereas productivity of education depends on the qualification of teachers. Teaching profession is a profession that requires numerous skills in complicating and rapidly changing information society. Teachers can develop their knowledge and skills at the end of some educational activities and as a result of this they can be better teachers. When the evaluations about a good teacher are examined, the definition "a teacher that improves himself personally and professionally, examines and evaluates occasions and opportunities about improving himself" attracts attention.

Today teachers need to have high professional standards in order to be successful. In information era continuous development of teachers and students are necessary to form information society. As the expectations from students increase, the expectations from teachers also increase. In order to raise better students and fulfill the requirements of students, teachers also continuously learn and improve themselves. Teachers have important role and responsibilities in achieving teaching profession and raising individuals in the direction of changing social requirements. The knowledge that teachers obtained in pre-service education period are not sufficient for them in achieving this role and responsibilities and can lose actuality. That is why in raising teacher one of the important stages besides pre-service education is in service training. For teachers professional development activities involve important period in their lifelong training.

Professional development is generally defined as making progress in one's career. Professional development of a teacher on the other hand is defined as advancement of teaching of a teacher with more experience and practice (Glatthorn 1995). According to Guskey (2000) that studied on professional development of teachers, it is a period and activities organized for developing professional knowledge, skill and attitudes of educators in order to improve their students. According to European Comission (2003) datas, it is defined as professional development, education quality and accordingly education that increases the quality of teacher. Professional development concept that can be defined as knowledge, skill and necessary circumstances for learning profession, recently becomes the most important factor in studies of educational development (Seferoğlu 2001).

Fullan (1991), defines professional development as a period that starts with the basic training of teachers and continues during their teaching career. Also he expresses that professional development cannot be separated from the development of school and both their development continues in accordance. In researches done regarding the development of teaching profession, it is expressed that professional training is a necessity to have better education and schools (Seferoğlu 2003).

Professional development is a total of learning activities contributing to increase the quality of education that are actualised intentionally and deliberately by aiming to avail teacher and school directly or indirectly (Bolam and McMahon 2004). Professional development of teachers are generally defined as in service training with activities involving courses, seminars done for training (Adey 2004). Professional development is defined as every kind of education and training activities that fulfill improvement and development requirements of teachers in profession. According to larger definition, professional development in teaching is total of aimed, continuous and systematic period and activities that are developed and designed in order to update, develop and increase their knowledge, skills and attitudes in managerial, personal, educational and subject field of teachers in order to provide development of school, reaching of determinated aims in education and improving learning of students. It can be said that in these definitions the contributions of professional development to teacher, student and school are emphasized.

Professional development is a sub period that takes place in lifelong training based on compensating shortages coming from pre-service trainings of teachers with in service training. That is why professional development has characteristic of a period that starts from pre-service training continues during starting of teaching and in service. Since expecting teachers to continue their profession with knowledge only from pre-service training cause teaching fall behind accordingly decrease in quality of education, teachers should continuously improve themselves. Villegas- 
Erdem, A., \& Koç, E. S. (2016). Classroom teachers' professional development activities within the scope of life long learning in Turkey. International Journal of Human Sciences, 13(1), 1503-1513. doi:10.14687/ijhs.v13i1.3698

Reimers and Reimers (2000), express that improving knowledge and skills of teachers with continuous professional development is an important stage in providing effective learning. Professional development involves formal experiences (participating workshops, meetings or visual activities etc.) and informal experiences (reading articles regarding profession, watching programs regarding academic dicipline etc.) (Ganser 2002). Professional development of teacher is possible by continuous obtaining of educational requirements in general culture field and taking precautions to compensate them. A teacher can be open to professional development as long as he is successful at being objective and improve his skills in evaluating himself (Gözütok 1991).

The aim of professional development is to support development of education system by gaining knowledge, skill and behaviors to teachers that is required by innovations and improvements in education field. In other words it does not only aim to improve qualifications and sufficiencies of a teacher with in service activities but also provides increase in success of students and classroom interaction. Professional development of teachers also make contributions to the development of students, school managers, parents of students, family members of teacher and other colleagues (Kabakç1 2007, Odabaşı and Kabakç1 2007). Shortly, an investment for teacher is an investment for individual which is a value for society. Accordingly professional development is a personal and social practice. In education period that is lifelong and social concept, educating of teacher just with modern understanding and approach in higher education programs are not considered sufficient (Ersoy 1998), learning process should also continue and last lifelong after graduation (Churukian 1995). Because the role of the teacher becomes more difficult in rapidly changing and complicating world (Aydin 1987), the teachers that were trained according to the qualified criterions of old can even become unqualified in a short time (Bülbül 1981).

If $73 \%$ of teachers in Turkey are thought to be under the age of 40 (Büyüköztürk et al. 2010), it can be said that the requirement of professional development is much. Especially for classroom teachers working in primary school that is the basis of all education stages, in service is necessary in order to improve the skills and compensate the demands of students of changing and renewing society. The aim of this research is to examine the activities that classroom teachers in Turkey participated in the scope of lifelong education aimed at providing professional development. In the scope of this research, the answers for the questions below directed to classroom teachers, were searched:

1) How many professional development activities did you attend in the recent year?

2) Which institution was professional development activity you attended, organized by?

3) What kind of professional development activities did you attend?

4) About which subjects did you attend professional development activities?

5) Did professional development activities you attended contribute your professional development?

6) According to you are professional development activities you attended sufficient?

7) Which subjects do you prefer to be held in professional development activities?

8) Apart from obligatory professional development activities you attended, what did you do for yourself?

\section{METHOD}

\subsection{Research Model}

In this descriptive model of research aiming to examine activities that class teachers in Turkey attended to provide professional development in the scope of lifelong training, survey model was used since revealing present situation was aimed. 
Erdem, A., \& Koç, E. S. (2016). Classroom teachers' professional development activities within the scope of life long learning in Turkey. International Journal of Human Sciences, 13(1), 1503-1513. doi:10.14687/ijhs.v13i1.3698

\subsection{Population and Sampling}

Public and private primary schools in Ankara province formed the population of this research done in fall term of 2014-2015 academic year. 220 classroom teachers serving in totally ten schools that are five private and five public, formed the sampling of this research. Easily accessible situational sampling method in sampling choice was applied. The research was conducted with participant teachers on a volunteer basis. The distribution of teachers participating in the study according to their grade level has been provided in Table 1.

Table 1. The distribution of teachers according to their grades

\begin{tabular}{ccc}
\hline Grades & f & \% \\
\hline $1^{\text {st }}$ Grade & 58 & 26.36 \\
$2^{\text {nd }}$ Grade & 61 & 27.73 \\
$3^{\text {rd }}$ Grade & 45 & 20.45 \\
$4^{\text {th }}$ Grade & 56 & 25.46 \\
\hline Total & 220 & 100 \\
\hline
\end{tabular}

As it is seen in Table 1, totally 220 teachers, 58 from $1^{\text {st }}$ grade, 61 from $2^{\text {nd }}$ grade, 45 from $3^{\text {td }}$ grade and 56 from $4^{\text {th }}$ grade were attended from the study. The distribution of teachers participating in the study according to their graduation status has been provided in Table 2.

Table 2. The distribution of teachers according to their graduation status

\begin{tabular}{lcc}
\hline Graduation levels & f & $\mathbf{0}$ \\
\hline Classroom Teacher & 136 & 62.82 \\
Other Teaching Departments & 31 & 14.09 \\
Fields Apart from Teaching & 53 & 24.09 \\
\hline Total & 220 & 100 \\
\hline
\end{tabular}

According to Table 2, approximately more than the half of the participant teachers graduated from class teaching department, it is seen that as an important rate, $38 \%$ of them graduated from other teaching departments and fields apart from teaching. Distribution of teachers participating in the study according to gender has been provided in Table 3 .

Table 3. The distribution of teachers according to gender

\begin{tabular}{lcc}
\hline Gender & f & $\mathbf{0}$ \\
\hline Female & 179 & 81.36 \\
Male & 41 & 18.64 \\
\hline Total & 220 & 100 \\
\hline
\end{tabular}

As it is seen in Table 3, it can be said that the number of participant female teachers is approximately more than four times of the number of participant male teachers.

\subsection{Data Collection Tools and Analysis of Data}

The questionnaire that was developed by researchers, was utilized as a data collection tool in the study. The data collected from class teachers under the scope of the study were presented as tables by examining their percentages and frequencies and also descriptive analysis were used.

\section{Findings and Interpretations}

In this part of the study, research findings and interpretations are given. Data collected from class teachers under the scope of the study have been grouped and presented in the form of tables. 
Erdem, A., \& Koç, E. S. (2016). Classroom teachers' professional development activities within the scope of life long learning in Turkey. International Journal of Human Sciences, 13(1), 1503-1513. doi:10.14687/ijhs.v13i1.3698

The distribution of opinions regarding the number of professional development activities that teachers attended in recent year, is given in Table 4.

Table 4. The distribution of opinions regarding the number of professional development activities that teachers attended in recent year

\begin{tabular}{lcc}
\hline Attended activity number & f & \% \\
\hline Never attended & 28 & 12.73 \\
Attended once & 57 & 25.91 \\
Attended twice & 63 & 28.64 \\
Attended three times & 49 & 22.27 \\
Attended four times or more & 23 & 10.45 \\
\hline
\end{tabular}

According to Table 4, most of the participant class teachers expressed that they attended once $(25 \%)$ or twice $(28 \%)$ to professional development activities in recent year. As $10 \%$ of class teachers expressed that they attended to activities four times or more whereas it is a remarkable finding that $10 \%$ of them never attended any activity in recent year. Professional development activities towards teachers can be organized by different people/institutions. The distribution of opinions regarding institutions organizing professional development activities that class teachers attended, is given in Table 5.

Table 5. The distribution of opinions regarding institutions organizing professional development activities that class teachers attended

\begin{tabular}{lcc}
\hline $\begin{array}{l}\text { Institution/Person Organizing } \\
\text { Activity }\end{array}$ & $\mathbf{f}$ & $\mathbf{\%}$ \\
\hline Ministery of Education & 83 & 27.39 \\
School Management & 76 & 25.08 \\
Specialist Guests & 42 & 13.86 \\
School Counselling Service & 34 & 11.22 \\
Other & 68 & 22.45 \\
\hline
\end{tabular}

According to the data in Table 5, most of the professional development activities are organized by Ministry of Education (\%27) and School Management (\%25). According to these data, it can be said that specialist guests and school counselling service are given less place in professional development activities. The distribution of opinions regarding types of professional development activities that class teachers attended, is given in Table 6.

Table 6. The distribution of opinions regarding types of professional development activities that classroom teachers attended

\begin{tabular}{lcc}
\hline Professional Development Activities & f & $\mathbf{\%}$ \\
\hline Seminar & 103 & 29.26 \\
Conference & 86 & 24.43 \\
Workshop & 72 & 20.46 \\
Work place & 57 & 16.19 \\
Other & 34 & 9.66 \\
\hline
\end{tabular}

As it is seen in Table 6, most of the class teachers attend seminar (29\%), conference (24\%) and workshops $(20 \%)$. It is seen that class teachers attend work places $(16 \%)$ less than others. According to this data, it can be said that seminars, conference and workshops are mostly, work place are less organized for professional development of teachers. The distribution of opinions regarding subjects of professional development activities that class teachers attended, is given in Table 7. 
Erdem, A., \& Koç, E. S. (2016). Classroom teachers' professional development activities within the scope of life long learning in Turkey. International Journal of Human Sciences, 13(1), 1503-1513. doi:10.14687/ijhs.v13i1.3698

Table 7. The distribution of opinions regarding subjects of professional development activities that classroom teachers attended

\begin{tabular}{llc}
\hline No & \multicolumn{1}{c}{ Subjects } & f \\
\hline 1 & Education method and techniques & 123 \\
2 & Active learning & 119 \\
3 & Classroom management & 117 \\
4 & Constructivist approach & 108 \\
5 & Counselling activities & 96 \\
6 & School-parent cooperation & 92 \\
7 & Computer and technology usage & 84 \\
8 & New approaches in education & 75 \\
9 & Creative drama & 63 \\
10 & Education of values & 57 \\
11 & Assessment and evaluation & 51 \\
12 & Total quality management & 42 \\
13 & Effective communication & 39 \\
14 & Foreign language & 36 \\
15 & Child development & 31 \\
16 & Legal regulations and applications & 27 \\
17 & Occupational health and safety & 19 \\
18 & Personalized education programs & 13 \\
19 & Fast reading techniques & 6 \\
\hline
\end{tabular}

According to Table 7, it is seen that classroom teachers mostly attend professional development activities regarding subjects such as education method and techniques, active learning, classroom management, constructivist approach, Counselling activities, school-parent cooperation, computer and technology usage, new approaches in education and creative drama. According to data in Table 7, it can be said that classroom teachers mostly attend professional development activities organized in the direction of approach in curriculum and differences in education in recent years. On the other hand it can be said that professional development activities are organized in terms of changes in curriculum. So classroom teachers will develop themselves in applications such as constructivist approach, active learning in professional development activities they attended and become more effective teachers. The distribution of opinions of classroom teachers regarding contributions of activities to their professional development, is given in Table 8 .

Table 8. The distribution of opinions of classroom teachers regarding contributions of activities to their professional development

\begin{tabular}{|c|c|c|c|}
\hline \multicolumn{2}{|r|}{ Contribution Situation to Professional Development } & \multirow{2}{*}{ f } & \multirow{2}{*}{$\begin{array}{c}\% \\
32.73\end{array}$} \\
\hline$\stackrel{\infty}{\circlearrowright}$ & $\begin{array}{l}\text { - My knowledge/skill increases } \\
\text { - I learn about innovations } \\
\text { - I can be more effective within class }\end{array}$ & & \\
\hline 坣 & $\begin{array}{l}\text { - I use technology more effective } \\
\text { - I make contact with families positively } \\
\text { - I strength my relation with my colleagues }\end{array}$ & 83 & 37.72 \\
\hline$\stackrel{\circ}{\mathrm{Z}}$ & $\begin{array}{l}\text { - The programs are not prepared effectively } \\
\text { - Nonspecialists provide training } \\
\text { - The programs do not take place at the right time and place } \\
\text { - Comigatory participation causes unwillingness } \\
\text { - Participation to programs is not encouraged }\end{array}$ & 65 & 29.55 \\
\hline
\end{tabular}

When Table 8 is examined, most of the classroom teachers (37\%) expressed that activities partially make contribution to their professional development. In their expressions that support their ideas they expressed that they use technology more effective, they make positive contact with families and strengthen their relation with their colleagues. According to the data in Table 7, even 
Erdem, A., \& Koç, E. S. (2016). Classroom teachers' professional development activities within the scope of life long learning in Turkey. International Journal of Human Sciences, 13(1), 1503-1513. doi:10.14687/ijhs.v13i1.3698

though classroom teachers mostly attend to the programs regarding innovations in curriculum, it is seen that there is more contribution in technology usage and communication with families and their colleagues. $32 \%$ of participant teachers express that activities make contribution to their professional development. They also mentioned that their knowledge and skills increase, they learn about innovations and being more effective with these activities. The data obtained in this section points the importance of professional development for effectiveness of teachers. $29 \%$ of participant class teachers informed that activities they attended do not make contribution to their profession development. Class teachers about this subject expressed that programs are not effectively prepared, nonspecialists provide training, programs do not take place at the right time and place, obligatory participation causes unwillingness, common subject/knowledge is given and participation of programs is not encouraged. Starting from this data based on the opinions of class teachers, it can be said that professional development will be more effective if there are alternatives with giving importance and priority to the subjects that teachers require, subjects are presented with interesting and applicable content by the help of specialists of this field and participation of teachers are provided in the direction of their choices. The distribution of opinions of class teachers about finding professional development activities sufficient, is given in Table 9.

When Table 9 is examined, it is seen that most of the participant teachers (35\%) find professional development activities that they attend partially efficient. In their expressions that support their opinions class teachers expressed that requirements and interests of teachers are not obtained, Effective planning is not made and senior educators in their fields is not chosen. $33 \%$ of participant class teachers expressed that they did not find professional development activities efficient. The reasons for this opinion are reported as they are not prepared according to the requirements of teachers, specialty, knowledge and experience are not considered, programs do not take place at the right time and place, common subjects and knowledge is given and school and its environment is not taken into consideration during preparation of programs.

Only 30\% of class teacher candidates expressed that they found professional development activities efficient. In this direction they said programs are presented by specialists of their field and information about innovations and improvements are given. According to the data in Table 9 show that although the number of teachers that give partially and no answers about finding professional development activities efficient form the majority, it is seen that there are considerable number of teachers that find these activities efficient.

Table 9. The distribution of opinions of classroom teachers about finding professional development activities sufficient

\begin{tabular}{|c|c|c|}
\hline Finding Professional Development Activities Sufficient & $\mathrm{f}$ & $\%$ \\
\hline $\begin{array}{l}\text { - Programs are effectively prepared } \\
\text { - They are given by specialists of their fields } \\
\text { - Information about innovations and improvements are given }\end{array}$ & 68 & 30.91 \\
\hline $\begin{array}{l}\text { - Requirements and interests of teachers are not obtained } \\
\text { - Effective planning is not made } \\
\text { - Senior educators in their fields is not chosen }\end{array}$ & 79 & 35.90 \\
\hline $\begin{array}{l}\text { - Programs are not prepared by taking the requirements of teachers into } \\
\text { consideration } \\
\text { - In programs specialty, knowledge and experience are not taken into } \\
\text { zonsideration } \\
\text { - Programs do not take place at the right time and place } \\
\text { - Common subjects/knowledge is given } \\
\text { - The school and its environment is not taken into consideration } \\
\text { during preparation of programs }\end{array}$ & 73 & 33.19 \\
\hline
\end{tabular}


Erdem, A., \& Koç, E. S. (2016). Classroom teachers' professional development activities within the scope of life long learning in Turkey. International Journal of Human Sciences, 13(1), 1503-1513. doi:10.14687/ijhs.v13i1.3698

Also, the close percentage of each three kinds of answers is also considered as an interesting finding. The distribution of opinions of classroom teachers about subjects that are required to be held in professional development activities, is given in Table 10.

Table 10. The distribution of opinions of class teachers about subjects that are required to be held in professional development activities

\begin{tabular}{llc}
\hline No & \multicolumn{1}{c}{ Subjects Required to be Held } & f \\
\hline 1 & Teaching-learning processes & 119 \\
2 & New approaches in education & 112 \\
3 & Developing activity within class & 104 \\
4 & Techniques of Recognizing a Student & 98 \\
5 & Counselling applications within class & 91 \\
6 & Creative drama activities & 82 \\
7 & Game based learning & 78 \\
8 & Effective usage of Technologies within class & 69 \\
9 & Education of parents & 62 \\
10 & Improving school-family cooperation & 54 \\
11 & Problem solving techniques & 45 \\
12 & Professional motivation & 38 \\
13 & Group work techniques & 32 \\
14 & Classroom management & 26 \\
15 & Assessment and evaluation & 17 \\
16 & Foreign education programs & 13 \\
17 & Cooperative learning & 8 \\
18 & Forming effective communication & 5 \\
\hline
\end{tabular}

According to the data in Table 10, the participant classroom teachers expressed that the required subjects in professional development activities are mostly as teaching-learning processes, new approaches in education, developing activity within class, techniques of recognizing a student, counselling applications within class, creative drama activities, game based learning and usage of technologies within class. It can be said that the participant class teachers mostly requires to be held professional development activities on subjects that encourage both recognizing student and providing them to learn in an entertaining condition such as creative drama, game based learning, group work, cooperative learning with innovations of curriculum and activities regarding applications within class. Besides they also emphasized that subjects such as education of parents, development of school-family cooperation and effective communication should be given place in professional development activities. In the direction of this data, it can be said that class teachers are aware of the importance of communication and family in education and also they think effective teaching can be provided by either the education of parents or strong school-family cooperation. The distribution of opinions of class teachers about what they are doing to improve themselves apart from the professional development activities they are obliged to attend, is given in Table 11.

Table 11. The distribution of opinions of classroom teachers about what they are doing to improve themselves apart from the professional development activities they are obliged to attend

\begin{tabular}{llc}
\hline No & Activities Towards Improving Themselves & f \\
\hline 1 & I follow up the internet & 103 \\
2 & I watch TV, listening to the radio & 95 \\
3 & I read daily newspapers & 86 \\
4 & I attend social and cultural activities & 78 \\
5 & I go to cinema/theatre & 71 \\
6 & I read books & 63 \\
7 & I follow up official writings at school & 54 \\
8 & I attend personal development activities & 47 \\
9 & I attend activities held by parents & 42 \\
10 & I attend weekend activities with my colleagues & 35 \\
11 & I go to foreign language course & 29 \\
\hline
\end{tabular}


Erdem, A., \& Koç, E. S. (2016). Classroom teachers' professional development activities within the scope of life long learning in Turkey. International Journal of Human Sciences, 13(1), 1503-1513. doi:10.14687/ijhs.v13i1.3698

\begin{tabular}{llc}
\hline 12 & I attend national symposium and congresses & 26 \\
13 & I attend postgraduate education programs & 17 \\
14 & I make domestic/foreign travel & 14 \\
15 & I attend folk dance activities & 9 \\
16 & I attend handicrafts/hobby activities & 6 \\
\hline
\end{tabular}

According to Table 11, apart from professional development activities they are obliged to attend, it is seen that class teachers follow up the internet, watch TV, listen to the radio, read newspaper, attend social and cultural activities and go to cinema/theatre in order to improve themselves. It can also be said class teachers mostly follow printed, visual and audial media for improvement. It is noticed that reading book is only expressed by 63 of teachers. Apart from these it is seen that class teachers attend activities in the direction of their interests such activities held by parents, folk dances and handicrafts as well as activities at specific themes such as foreign language course, national symposiums and congresses. Only 17 of class teachers attending postgraduate program is considered as a rather significant finding.

\section{Discussion, Conclusion and Recommendations}

In this research the activities that provides professional development in lifelong training scope of class teachers in Turkey, were examined. In this direction totally opinions of 220 teachers of $1^{\text {st }}$, $2^{\text {nd }}, 3^{\text {rd }}$ and $4^{\text {th }}$ grades serving in public and private schools in Ankara province, were taken. According to the opinions of participant class teachers most of them attend professional development activities once $(25 \%)$ or twice $(28 \%)$ in recent year. Most of the professional development activities that class teachers attend are held by Ministry of Education $(27 \%)$ and school management $(25 \%)$. Most of the class teachers attend seminars $(29 \%)$, conferences $(24 \%)$ and workshops (20\%), participation to work places are less in number (16\%). Most of the professional development activities that class teachers attend are related with education method and techniques, active learning, classroom management, constructivist approach, counselling activities, school-family cooperation, usage of technology and computer, new approaches in education and creative drama. Most of the class teachers (37\%) reported activities that they attend partially contribute to their professional development. By attending these activities they expressed that they use technology more effective, form positive communication with families and strengthen relations with their colleagues. $32 \%$ of class teachers reported activities that they attend contribute to their professional development whereas $29 \%$ said they do not. Most of the class teachers $(35 \%)$ reported activities that they attend are partially sufficient, 33\% find them insufficient and 30\% find them sufficient.

The subjects that participant class teachers require to be held are mostly teaching-learning processes, new approaches in education, developing activity within class, techniques of recognizing a student, counselling applications within class, creative drama activities, game based learning and usage of technology within class. Apart from obligatory professional development activities class teachers follow up the internet, watch TV, listen to the radio, read newspaper, attend social and cultural activities and go to cinema/theatre in order to improve themselves. According to report of Teaching and Learning International Survey 2010 - (TALIS) (Büyüköztürk et al. 2010), approximately $20 \%$ of teachers expressed that professional activities such as course/workshop and conference/seminar has "no" or "a little" effect on their developments.

Similarly because of studies regarding professional development mostly stand on narration and demonstration, disusing of examples towards practice (K1ldan 2008), the opinions of teachers from different branches regarding professional development are generally negative (Aydoğan 2002, Çiftçi 2008). According to report of Teaching and Learning International Survey 2010- (TALIS).

Turkey has a young teacher staff however their professional development requirements are not exactly determined and most of the teachers think that professional development activities they attended are insufficient (Büyüköztürk et al. 2010). As Özer (2004) expressed professional development requirements are their interests and attitudes. At this point, the subjects in 
Erdem, A., \& Koç, E. S. (2016). Classroom teachers' professional development activities within the scope of life long learning in Turkey. International Journal of Human Sciences, 13(1), 1503-1513. doi:10.14687/ijhs.v13i1.3698

professional development activities should be aimed at real requirements (needs analysis) of teachers and practices should be monitored (Aydoğan 2002, Bayrakçı 2009, Çiftçi 2008, Demirkol 2010, Özer 2004 and Özoğlu 2010).

Even though professional development activities contain innovations in curriculums, the importance and priority can be given to the subjects that teachers require. Since class teachers are practitioners of the curriculum in the class, there can be more within class activities such as recognizing student in details, learning with fun. Accordingly, professional development activities can become an effective process for teachers in which they increase their experiences with application examples shared by specialists instead of informing. In a way as Uşun (2008), Gönen and Kocakaya (2006) suggested performed professional development activities can be regulated to be more useful and functional by evaluating effectively.

The less number (17) of class teachers attending postgraduate education programs show that postgraduate education is substantially preferred in terms of professional development. Teachers consider distance education professional development activities positively since they provide time and place flexibility (Baran and Çağgltay 2006). About this subject, formal and distance postgraduate programs without thesis towards teachers can be conducted. On the other hand, if class teachers are offered right of choosing about professional development activities, it is thought that they will be volunteer to attend activities in terms of their interests and requirements.

The other important suggestion is planning of professional development activities in a way that can be reached by teachers during academic year instead of limiting them with specific time periods in a year. Education activities in modules with opinions of class teachers can be regulated and in computer environment these modules can be accessed at any time. In this way, class teachers that have great responsibilities in training individuals in the direction of requirements of changing world, continuously update themselves by attending different activities at any time they want during education-training period, can make more contributions to the students, school and accordingly to the society by increasing their experience.

\section{REFERENCES}

Adey P 2004. The Professional Development of Teachers: Practica and Theory. London: Kluwer Academic Publishers.

Aydın M 1987. Bir Hizmet içi eğitim olarak denetim. Hacettepe Üniversitesi Eğitim Fakültesi Dergisi, “Çağdaş Gelişmeler Işığında Türkiye'de Eğitim Fakültelerinin Yeri ve Rolü”, International Conference (17-19 November 1986) Special Issue, 2:241-249.

Aydoğan İ 2002. MEB İlkögretim okullar yönetici ve ögretmenlerinin personel geliștirmeye ilişkin görïsleri (Kayseri ili örneği). Unpublished doctorate thesis. Ankara University.

Baran B, Çağıltay K 2006. Teachers' experiences in online professional development environment. Turkish Online Journal of Distance Education-TOJDE, 7(4):110-122.

Bayrakçı M 2009. In-service teacher training in japan and turkey: a comparative analysis of institutions and practices. Australian Journal of Teacher Education, 34(1): 10-22.

Bolam R, McMahon A. 2004. Literature, definitions and models: towards a conceptual map. Inretnational Handbook on the Continuing Professional Development of Teachers, Ed.: C. Day, J. Sachs. Maidenhead: Open University Pres.

Bülbül S 1981. Öğretmenin değişen rolü: nitelik ve verimlilikle ilgili bazı sorunlar. Milli Eğitim Dergisi, p. 47-50.

Büyüköztürk Ş, Akbaba-Altun S, Yıldırım K 2010. Teaching and learning international survey (TALIS), Ankara. 
Erdem, A., \& Koç, E. S. (2016). Classroom teachers' professional development activities within the scope of life long learning in Turkey. International Journal of Human Sciences, 13(1), 1503-1513. doi:10.14687/ijhs.v13i1.3698

Churukian A G 1995. Avrupa Konseyi ülkeleri'nde öğretmen eğitimi politika modelleri: sonuç raporu ve tavsiyeler. Avrupa Konseyi Ülkeleri Öğretmen Yetiştirme Politika ve Modelleri (21-26 September 1992, İzmir), MEB, Ankara, p. 243-246.

Çiftçi E 2008. Türkiye'de milli eğitim bakanlığı tarafindan müzik öğretmenlerine verilen hizmetiçi eğitimin incelenmesi ve müzik öğretmenlerinin hizmetiçi eğitim ihtiyaçlarının belirlenmesi. Unpublished doctorate thesis. Gazi University.

Demirkol M 2010. İlköğretim okullarında öğretmenlere yönelik okul-temelli hizmet içi eğitim etkinliklerinin değerlendirilmesi. Milli Eğitim Dergisi, 188:158-173.

Ersoy Y 1998. Öğretmenlikte yeterlilik ve yetkinlik değerlendirmesi. Çăgdaş Ĕ̈itim Dergisi, 246:5-9.

ETUCE - European Trade Union Committee for Education 1995. Teacher Education in Europe. Brussels. http://www.see-educoop.net/education_in/pdf/etuce_report_1995-01-oth-enlt05.pdf

Fullan M G 1991. The new meaning of educational change. New York: Teachers College Press.

Ganser T 2002. The new teacher mentors: Four trends that are changing the look of mentoring programs for new teachers. American School Board Journal, 189 (12): 25-27.

Glatthorn A 1995. Teacher development. Anderson. L. (ed.), International Encyclopaedia of Teaching and Teacher Education (second edition). London: Pergamon Pres.

Gönen S, Kocakaya S 2006. Fizik öğretmenlerinin hizmet içi eğitimler üzerine görüşlerinin değerlendirilmesi. Pamukkale Üniversitesi Ë̆itim Fakültesi Dergisi, 19(1): 37-44.

Guskey T R 2000. Evaluating professional development. Corwin Press, California.

Gürlen E, Demirel Ö 2010. Avrupa Birliği ve Türkiye'deki öğretmen yeterliklerin karşılaştırmalı incelenmesi. Proceedings of International Conference on Teacher Training Policies and Problems II, 396401.

Odabaşı H F, Kabakçı I 2007. Öğretmenlerin mesleki gelişimlerinde bilgi ve iletişim teknolojileri. Uluslararası Öğretmen Yetiştirme Politikalar ve Sorunlar Semposyumu, Azerbaycan: Bakü.

Kabakçı I 2007. Sınıf öğretmenlerinin mesleki gelişiimi ve öğretim teknolojileri. Öğretim Teknolojileri ve Materyal Tasarmı. Ed.: H. Ferhan Odabaşı, Eskişehir: Anadolu Üniversitesi Yayınları, 1752.

Kıldan A O 2008. Yapılandırmacı yaklaşıma göre okul öncesi öğretmenlerine verilen hizmetiçi eğitimin öğretmen-çocuk ve öğretmen-ebeveyn ilisskilerine etkisi. Unpublished doctorate thesis. Gazi University.

Özer B 2004. In-service training of teachers in Turkey at the beginning of the 2000s. Journal of inservice Education, 30(1): 89-100.

Özoğlu M 2010. Hiæmetiçi eğitimde sorunlar ve çöæüm önerileri. http://hedb.meb.gov.tr/net/_duyuru_dosyalar/calistay.pdf

Seferoğlu S S 2001. Elementary school teachers' perceptions of professional development. Hacettepe Üniversitesi Ë̆itim Fakültesi Dergisi, 20:117-125.

Seferoğlu S S 2003. Öğretmenlerin hizmet-içi eğitiminde yeni yaklaşımlar. Căğdaş Eğitim Sistemlerinde Ögretmen Yetiştirme Ulusal Semposyumu, Eğitimde Yansimalar: VII, p. 149-167.

Uşun S 2008. A review of the new approaches and problems of the Turkish teacher education system. Cypriot Journal of Educational Sciences, 3(2):57-67.

Villegas R E, Reimers F 2000. Professional development of teachers as lifelong learning: Models, practices and factors that influence it. Paper prepared for the Board on International Comparative Studies in Education of the National Research Council. Washington, D.C. 